\title{
Otopalatodigital syndrome type 2
}

INSERM

\section{Source}

INSERM. (1999). Orphanet: an online rare disease and orphan drug data base.

Otopalatodigital syndrome type 2. ORPHA:90652

Otopalatodigital syndrome type 2 (OPD2) is a severe form of otopalatodigital syndrome spectrum disorder, and is characterized by dysmorphic facies, severe skeletal dysplasia affecting the axial and appendicular skeleton, extraskeletal anomalies (including malformations of the brain, heart, genitourinary system, and intestine) and poor survival. 